\title{
Ticks, Demographics, Vegetation Cover, and Farmer's Age Influence Red Meat Production in Resource-Poor Regions of Eastern Cape Province of South Africa
}

\author{
Nkululeko Nyangiwe ${ }^{1,2 *}$, Sindisile Goni ${ }^{1}$, Thami Khethani' ${ }^{1}$, Tanki Thubela1, Mlungisi Jansen', \\ Siza Mthi', Mandla Yawa ${ }^{3}$, Sive Tokozwayo¹, Unathi Gulwa', Ntanganedzeni O. Mapholi²,

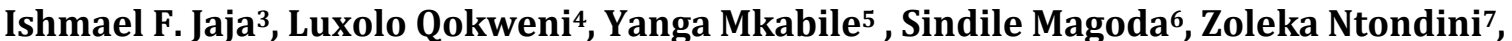 \\ Zamantungwa T. H. Khumalo8,9 \\ ${ }^{1}$ Döhne Agricultural Development Institute, Stutterheim, South Africa \\ ${ }^{2}$ Department of Agriculture and Animal Health, University of South Africa, Florida, South Africa \\ ${ }^{3}$ Department of Livestock and Pasture Science, Faculty of Science and Agriculture, University of Fort Hare, Alice, \\ South Africa \\ ${ }^{4}$ Department of Rural Development and Agrarian Reform, Kokstad, South Africa \\ ${ }^{5}$ Department of Rural Development and Agrarian Reform, Bathurst, South Africa \\ ${ }^{6}$ Department of Rural Development and Agrarian Reform, Port Elizabeth, South Africa \\ ${ }^{7}$ Department of Rural Development and Agrarian Reform, Queenstown, South Africa \\ ${ }^{8}$ National Institute for Communicable Diseases, Sequencing Core Facility, National Health Laboratory Service, Johannesburg, \\ South Africa \\ ${ }^{9}$ Department of Veterinary Tropical Diseases, Faculty of Veterinary Science, University of Pretoria, Onderstepoort, \\ South Africa \\ Email: nyangiwe1@gmail.com
}

How to cite this paper: Nyangiwe, N., Goni, S., Khethani, T., Thubela, T., Jansen, M., Mthi, S., Yawa, M., Tokozwayo, S., Gulwa, U., Mapholi, N.O., Jaja, I.F., Qokweni, L., Mkabile, Y., Magoda, S., Ntondini, Z. and Khumalo, Z.T.H. (2021) Ticks, Demographics, Vegetation Cover, and Farmer's Age Influence Red Meat Production in Resource-Poor Regions of Eastern Cape Province of South Africa. Open Journal of Animal Sciences, 11, 682-696.

https://doi.org/10.4236/ojas.2021.114046

Received: August 17, 2021

Accepted: October 23, 2021

Published: October 26, 2021

\section{Abstract}

This study presents an integrated examination of livestock production constraints associating with communal farming in six district municipalities (DMs) of the Eastern Cape Province. We collected data on demographic and socio-economic factors from 271 farmers randomly given questionnaires. About 26 Land Redistribution for Agricultural Development (LRAD) owned by communal farmers were surveyed to ascertain the condition of grazing land, meanwhile, tick species and distribution on cattle and goats found in 158 sampling sites of the study area were also recorded. From the results, a total of 34,929 adult ticks belonging to five genera and 10 species were encountered. The most abundant tick genera were Rhipicephalus of the subgenus Boophilus (68.91\%), Amblyomma (20.72\%), Hyalomma (8.64\%), Ixodes (1.22\%), and Haemaphysalis (0.51\%). By geographic distributions, Am- 
Copyright $\odot 2021$ by author(s) and Scientific Research Publishing Inc. This work is licensed under the Creative Commons Attribution International License (CC BY 4.0).

http://creativecommons.org/licenses/by/4.0/

Open Access blyomma and Rhipicephalus were common to all DMs, while $R$. microplus and $R$. decoloratus were found in the drier regions. From the map plotted for 16 custom feeding centers, lack of marketing channels (23\%), poor animal conditions (20\%), lack of infrastructure (19\%), high price of medicine (14\%), shortage of feed (10\%), stock theft (8\%), and age of animals (too old) to be marketed $(6 \%)$ are the major shortcomings in red meat production. We found that the associations between gender $\left(\chi^{2}=31.3481, p<0.0001\right)$, age $\left(\chi^{2}\right.$ $=32.4889, p<0.0001)$, and farming experience $\left(\chi^{2}=52.7556, p<0.0001\right)$ were significantly $(p<0.05)$ higher. Additionally, we found that farming commodities were significantly influenced by gender and farming experience. From the surveyed LRAD farms, we observed a higher proportion of increaser II grass species in Alfred Nzo (55.6\%), Amathole (53.9\%), and Chris Hani (46.4\%) DMs. On the other hand, the decreaser grass species were few in Alfred Nzo (16.5\%), Amathole (13.8\%), and Chris Hani (21.8\%). Inferences from the data indicate the need for government and stakeholders' intervention to farmers through the provision of infrastructures, marketing channels, and training on livestock based programs.

\section{Keywords}

Amblyomma, Constraints, Rangeland Conditions, Rhipicephalus (Boophilus) microplus, Tick Distribution, South Africa

\section{Introduction}

The overall demand for the livestock product is greatly increasing by contributing $30 \%$ of agricultural products and $2.5 \%$ to the country's Gross Domestic Product in South Africa [1] [2]. In the nine provinces of South Africa, the Eastern Cape Province (ECP) is endowed with different agro-ecological zones for crop and livestock production. Biomes such as Albany Thicket, Forest, Fynbos, Grassland, Indian Coastal Belt, Nama-Karoo, Savanna and Succulent Karoo in the ECP [3], make the ECP second in terms of the land size $\left(168,966 \mathrm{~km}^{2}\right)$. About $80 \%$ of the land is suitable for a larger herd of cattle, sheep, and goats production [4]. Currently, agricultural practices involving communal farming systems do not have an adequate monitoring system that controls the availability of grazing resources, coupled with poor animal husbandry practices that have resulted in lower offtake per annum [5].

Through interacting with farmers and previous records, we found several reasons such as inadequate infrastructure, costs of inputs, poor funding, overstocking and overgrazing, degraded natural resources, low reproduction rate, insufficient extension and veterinary services, limited access to the market, tick burdens and disease prevalence, influencing communal farming in this region [6] [7] [8] [9]. In spite that the effort of the National Development Plan (NDP) for 2030 in South Africa involves agricultural practices that will create millions of jobs for the youths in the rural community [10], previous records (e.g. [6] [7] 
[8] [9]) found that the involvement of youths in agricultural practices such as farming and livestock production remains insufficient. Besides that, the communal farming system is hampered by the condition of the rangeland animals use to graze. For instance, the invasion of grazing fields by alien plants e.g. Acacia species, Acacia mearnsii, and the Vachellia karroo that pose a serious threat to fodder production [3] [11], and the occurrence of ticks and tick-borne diseases (TBDs) have been obstructing production in this region. Ticks of the genera Amblyomma, Hyalomma, Rhipicephalus including the subgenus Boophuilus [12] and tick-borne diseases (TBDs) such as babesiosis anaplasmosis, and theileriosis [13] [14] [15] are common to ruminants of the ECP. The buying and movement of cattle promote tick distribution to a new environment. For instance, the spread of the invasive tick (Rhipicephalus microplus) in the ECP has displaced the indigenous tick ( $R$. decoloratus) [15] [16]. Despite these factors, continuity in monitoring is limited, therefore, the objective of this study is to determine the factors that could influence beef production in communal farming areas of the ECP.

\section{Materials and Methods}

\subsection{Study Area}

The ECP is a rural area located between the Western Cape and KwaZulu-Natal provinces. The region occupies about $13.9 \%$ of South Africa's land area and it is the second largest after the Northern Cape. The ECP is divided into two metropolitan municipalities (Buffalo City and Nelson Mandela Bay) and six DMs, namely Alfred Nzo, Amathole, Chris Hani, Joe Gqabi, Oliver Reginald Tambo (O. R. Tambo) and Sarah Baartman (Figure 1). The district municipalities are further divided into 31 local municipalities. The climatic condition of the ECP involves a bimodal rainfall pattern that includes a winter rainfall and a summer rainfall [3] [17]. The rainfall in the province varies between $100 \mathrm{~mm}$ and 520 $\mathrm{mm}$ per annum. During winter, temperature ranges from $7^{\circ} \mathrm{C}$ to $20^{\circ} \mathrm{C}$, while in summer, temperature ranges from $16^{\circ} \mathrm{C}$ to $26^{\circ} \mathrm{C}$. Of the six DMs, five are involved in farmer profiling and red meat production. With the province having a total of 16 custom feeding centres that are communal based in livestock production of cattle and sheep, thus, ticks were screened from these six DMs.

\subsection{Socio-Demographic Profile}

An attempt was made to interview 10 - 15 farmers per local municipalities of the participating DMs. Data on demographic factors were collected using questionnaire for 271 farmers involved in farming commodities in Alfred Nzo $(\mathrm{n}=51)$, Amathole ( $\mathrm{n}=54)$, Chris Hani $(\mathrm{n}=57)$, Joe Gqabi $(\mathrm{n}=50)$ and O. R. Tambo ( $=59$ ). The information regarding red meat production was obtained from the farmers and the custom feeding centers located in the participating DMs.

\subsection{Vegetation Sampling}

In each DMs (Alfred Nzo, Amathole \& Chris Hani), a group of communal 


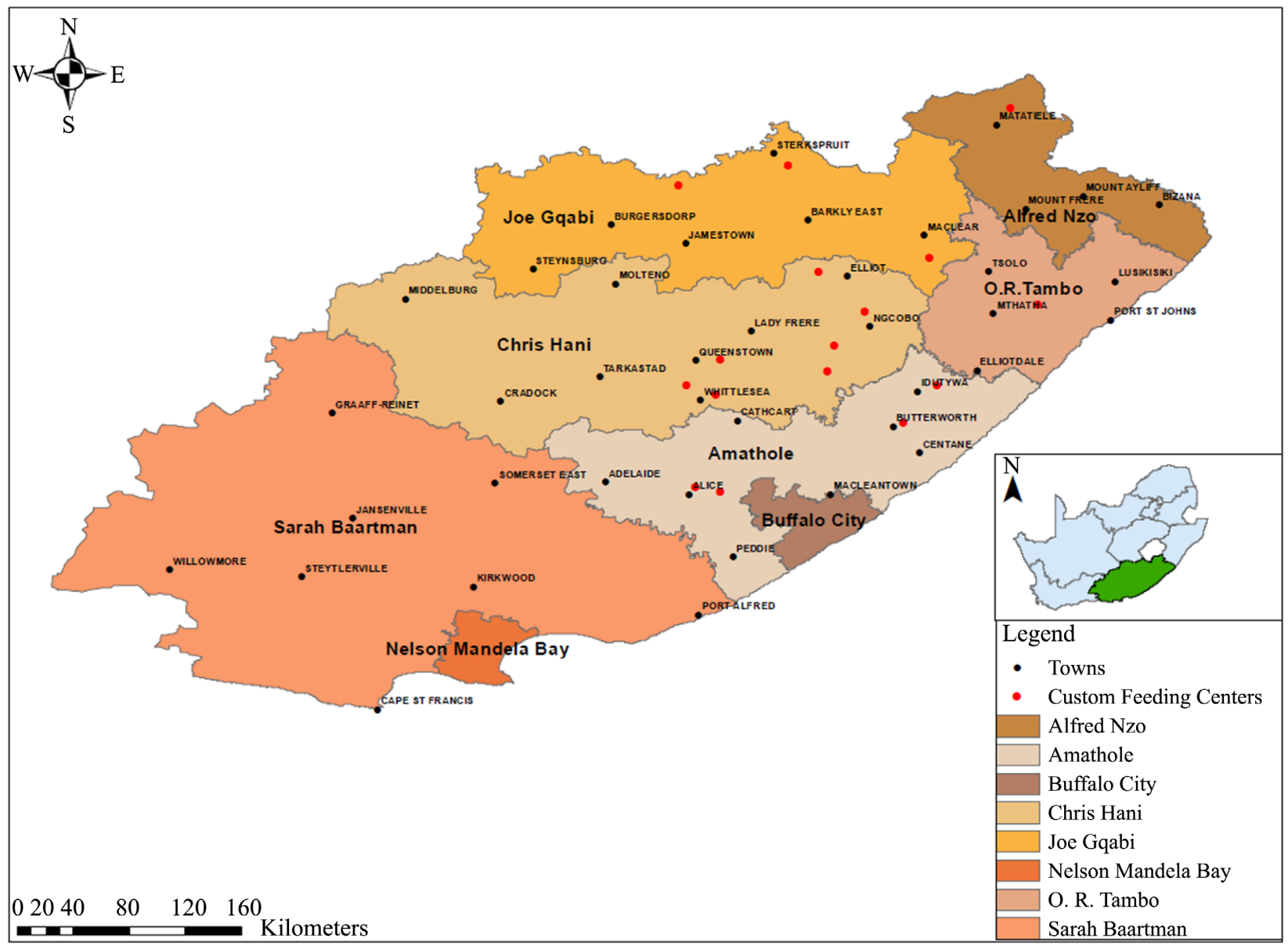

Figure 1. Map of the Eastern Cape Province, showing the custom feeding centers for red meat production survey.

farmers were granted farms under the program known as Land Redistribution for Agricultural Development (LRAD) for the production of cattle, sheep and goats Of the five participating DMs, veld condition was conducted between nine and 10 farms per district randomly selected to show rangeland productivity. At each site, three $100 \mathrm{~m}$ parallel transects were laid out $25 \mathrm{~m}$ apart. Botanical composition and the basal cover of the herbaceous layer were assessed using the step point method and within belt transect, woody plant species were identified and counted to evaluate their composition [18].

\subsection{Tick Collection}

Ticks were screened from five cattle selected randomly in twenty diptanks found across the six DMs visited. The ears, bodies, bellies, feet, tails and peri-anal regions of the animals were screened once in every visit to the DMs. The ticks collected were stored in well labelled vials containing 70\% ethanol, before transporting to the Döhne Agricultural Development Institute in Stutterheim and identified on a stereoscopic microscope. In the laboratory, ticks were identified based on morphology [19] and the aid of taxonomic keys of [20] and the reference ticks found in the museum of the University of Pretoria. 


\subsection{Data Analysis}

Data for farmer's demographic and farming commodity were subjected to [21], version 9.1 for analysis. Frequencies were determined using the PROC FREQ procedures [21]. The chi-square test was used to determine associations between the farmer's demographic information and farming commodities. Correlation coefficients for farmers' demography and their farming commodities were determined using PROC CORR procedures of [21]. In all cases, 95\% confidence intervals and $p<0.05$ were set for statistical significance. Meanwhile, geographic coordinates of each sampled site for ticks were used to plot the distributions of tick species in QGIS v 2.6.1 [22].

\section{Results}

\subsection{Custom Feeding Centers Distribution}

In an endeavour to collect information on red meat production for communal farming areas, a survey on customer feeding centers was done in five DMs (Figure 1). All the custom feedlot centers were visited and data regarding intake capacity was recorded. However, none of the 16 centers have achieved $100 \%$ operational status when comparing intake capacity with current numbers of animals. From the 271 farmers interviewed across the five DMs, the common challenges for red meat production were lack of marketing channels (23\%), poor animal conditions (20\%), lack of infrastructure (19\%), high price of medicine (14\%), shortage of feed (10\%), stock theft ( $8 \%)$, and age of animals (too old) to be marketed (6\%).

\subsection{Farmers' Socio-Demographic Profile}

Table 1 shows the demographic profiles of 271 farmers who participated in the study. The majority of the respondents were males (67\%) compared to females (33\%). The highest numbers of farmers (26\%) were between ages $41-50$ years old, proceeded by $51-60$ years old (21\%). Most of the (32\%) farmers were between 21 - 25 years of farming experience, proceeded by 16 - 20 years (15\%), 11 15 years (18\%), above 26 years (13\%) and less than 5 years (10\%). the farmer's demography and farming commodities were conducted and there was a significantly strong correlation $(p \leq 0.001)$ between farming commodity and farming area (Table 2). We also found that farming commodities (such as livestock, poultry and piggery) were significantly influenced by gender and farming experience while age was not significant $(p>0.05)$.

\subsection{Vegetation Assessment}

Results from Tables 3-5 indicate the condition of veld in the three surveyed districts (Alfred Nzo, Amathole and Chris Hani Districts). It was observed that numerous farms were overstocked per each district during the survey. About $80 \%$ and 70\% of farms in Alfred Nzo (Table 4) and Chris Hani District (Table 3) were overstocked, while the understocked (80\%) farms were found in Amathole 
Table 1. Farmers' demographic information.

\begin{tabular}{|c|c|c|c|c|}
\hline Items & Frequency $(n=271)$ & Proportion (\%) & $\chi^{2}$ test & $p$-value \\
\hline \multicolumn{5}{|l|}{ Gender } \\
\hline Male & 182 & 67.04 & 31.3481 & $<0.0001$ \\
\hline Female & 89 & 32.96 & & \\
\hline Total & & 100 & & \\
\hline \multicolumn{5}{|l|}{ Age } \\
\hline$\leq 20$ & 23 & 8.52 & 32.4889 & $<0.0001$ \\
\hline $21-30$ & 31 & 11.48 & & \\
\hline $31-40$ & 47 & 17.41 & & \\
\hline $41-50$ & 70 & 25.93 & & \\
\hline $51-60$ & 57 & 21.11 & & \\
\hline$\geq 61$ & 42 & 15.56 & & \\
\hline Total & & 100 & & \\
\hline \multicolumn{5}{|c|}{ Farming experience } \\
\hline$\leq 5$ & 28 & 10.37 & 52.7556 & $<0.0001$ \\
\hline $6-10$ & 31 & 11.48 & & \\
\hline $11-15$ & 48 & 17.78 & & \\
\hline $16-20$ & 41 & 15.19 & & \\
\hline $21-25$ & 87 & 32.22 & & \\
\hline$\geq 26$ & 35 & 12.96 & & \\
\hline Total & & 100 & & \\
\hline
\end{tabular}

Table 2. Correlations amongst the farmer's demography and farming commodities.

\begin{tabular}{ccccc}
\hline & Commodity & Area & Gender & Age \\
\hline Area & $0.277^{* *}$ & & & \\
Gender & $0.198^{*}$ & $0.171^{*}$ & $0.119^{\mathrm{NS}}$ & $0.064^{\mathrm{NS}}$ \\
Age & $0.081^{\mathrm{NS}}$ & $0.099^{\mathrm{NS}}$ & $0.135^{\mathrm{NS}}$ & $0.222^{*}$ \\
\hline Farming experience & $0.119^{*}$ & & & \\
\hline
\end{tabular}

Significant at ${ }^{*} p \leq 0.05$, significant at ${ }^{* *} p \leq 0.001$ and NS not significant at $p \geq 0.05$.

Table 3. The calculated grazing capacities, expected, and current animal units per farm and utilization status of selected LRAD farms in Chris Hani region.

\begin{tabular}{cccccccc}
\hline Farm Name & $\begin{array}{c}\text { Veld } \\
\text { Code }\end{array}$ & $\begin{array}{c}\text { Veld Condition } \\
(\%)\end{array}$ & $\begin{array}{c}\text { Calc. GC } \\
\text { (Ha/AU) }\end{array}$ & $\begin{array}{c}\text { Farm Size } \\
\text { (ha) }\end{array}$ & $\begin{array}{c}\text { Expected } \\
\text { (AU/Farm) }\end{array}$ & $\begin{array}{c}\text { Current } \\
\text { (AU/Farm) })\end{array}$ & Understocked (+)/Overstock (-) \\
\hline Sunset Farm & Gd 3 & 71.3 & 8.4 & 280 & 33 & 74 & -41 \\
Amatshezi & Gd 4 & 81.2 & 5.5 & 381 & 69 & 61 & 8 \\
Cromedale & Gs 15 & 79.6 & 2.5 & 649 & 260 & 150 & 110 \\
Drofontein & Nku 4 & 28.0 & 21.4 & 1257 & 59 & 107 & -48 \\
\hline
\end{tabular}


Continued

\begin{tabular}{|c|c|c|c|c|c|c|c|}
\hline Harmony & Nku 4 & 24.1 & 24.9 & 960 & 39 & 73 & -34 \\
\hline Galafontein & Gd 4 & 37.9 & 11.9 & 450 & 38 & 264 & -226 \\
\hline Songa-Ifa & Gs 16 & 42.9 & 7 & 1069 & 153 & 156 & -3 \\
\hline Indyebo & Gh 1 & 42.1 & 14.3 & 984 & 69 & 143 & -74 \\
\hline Greenvale & Gd 3 & 34.2 & 17.6 & 800 & 45 & 127 & -82 \\
\hline Fairfield & Gd 2 & 68.6 & 2.9 & 1982 & 683 & 389 & 294 \\
\hline
\end{tabular}

Gd-Drakensberg Grassland; Gs-Sub-Escarpment Grassland; Nku-Upper Karoo; Gh-Dry Highveld Grassland; Ha/AU-hectare per animal unit; Calc. GCCalculated Grazing Capacity.

Table 4. The calculated grazing capacities, expected, and current animal units per farm and utilization status of selected LRAD farms in Alfred Nzo region.

\begin{tabular}{|c|c|c|c|c|c|c|c|}
\hline Farm Name & $\begin{array}{l}\text { Veld } \\
\text { Code }\end{array}$ & $\begin{array}{c}\text { Veld Condition } \\
(\%)\end{array}$ & $\begin{array}{l}\text { Calc. GC } \\
(\mathrm{Ha} / \mathrm{AU})\end{array}$ & $\begin{array}{l}\text { Farm Size } \\
\quad(\mathrm{Ha})\end{array}$ & $\begin{array}{l}\text { Expected } \\
\text { AU/Farm }\end{array}$ & $\begin{array}{c}\text { Current } \\
\text { AU/Farm }\end{array}$ & Understocked (+)/Overstock (-) \\
\hline Rosseleigh & Gs $12 / 13$ & 53.93 & 6.7 & 364 & 54 & 113 & -59 \\
\hline Hentic & Gs 13 & 32.79 & 14.8 & 1200 & 81 & 83 & -2 \\
\hline Vleidraai & Gs 10 & 48.99 & 4.4 & 529 & 121 & 83 & 37 \\
\hline Colenbert & Gs 13 & 45.19 & 10.2 & 938 & 92 & 143 & -51 \\
\hline Zandfontein & Gs 13 & 41.44 & 11.3 & 401 & 35 & 94 & -59 \\
\hline Driefontein & Gs 12 & 72.76 & 3.2 & 785 & 245 & 496 & -250 \\
\hline Hanover & Gs 12 & 82.39 & 2.7 & 944 & 350 & 113 & 237 \\
\hline Claybrook & Gs $12 / 13$ & 88.59 & 4.1 & 1091 & 266 & 98 & 168 \\
\hline Maringe & Gs 13 & 40.01 & 11.4 & 824 & 72 & 333 & -260 \\
\hline Honey Kloof & Gs 10 & 51.66 & 3.9 & 650 & 168 & 55 & 113 \\
\hline
\end{tabular}

Gs-Sub-Escarpment Grassland; GC-Grazing capacity; AU-Animal Unit; Ha/AU-hectare per animal unit; Calc. GC-Calculated Grazing Capacity.

Table 5. The calculated grazing capacities, expected, and current animal units per farm and utilization status of selected LRAD farms in Amathole region.

\begin{tabular}{cccccccc}
\hline Farm Name & $\begin{array}{c}\text { Veld } \\
\text { Code }\end{array}$ & $\begin{array}{c}\text { Veld Condition } \\
(\%)\end{array}$ & $\begin{array}{c}\text { Calc. GC } \\
(\mathrm{Ha} / \mathrm{AU})\end{array}$ & $\begin{array}{c}\text { Farm Size } \\
(\mathrm{Ha})\end{array}$ & $\begin{array}{c}\text { Expected } \\
\text { AU/farm }\end{array}$ & $\begin{array}{c}\text { Current } \\
\text { AU/farm }\end{array}$ & Understocked (+)/Overstock (-) \\
\hline Mthimkhulu & SVs8 & 47.57 & 5.73 & 284 & 49.58 & 69.00 & -19.42 \\
Impanele & SVs7/SVs6 & 33.33 & 9.12 & 641 & 70.25 & 123.00 & -52.75 \\
Laphumikhwezi & Gs18 & 78.19 & 2.61 & 1300 & 498.79 & 44.00 & +454.79 \\
Buxton & AT28/AT32 & 48.60 & 6.26 & 300 & 47.89 & 41.00 & +6.89 \\
Gcinubuzwe & Gd1/Gs15 & 71.16 & 3.03 & 900 & 297.18 & 276.00 & +21.18 \\
Melisizwe & SVs7/Gd1 & 57.83 & 4.55 & 347 & 76.26 & 14.00 & +62.26 \\
Stemele & SVs7 & 55.73 & 4.51 & 295 & 65.45 & 30.00 & +35.45 \\
Madliwa & SVs7/AT21 & 54.10 & 4.92 & 378 & 76.84 & 24.00 & +52.84 \\
Dingela & AT56 & 56.66 & 4.49 & 450 & 100.22 & 83.00 & +17.22 \\
\hline
\end{tabular}

SVs-Sub-Escarpment Savanna; Gs-Sub-Escarpment Grassland; Gd-Drakensberg Grassland; AT-Albany Thicket; GC-Grazing Capacity; AU-Animal Unit. 
LRAD (Table 5). Based on vegetation assessment of the farms, a greater proportion of increaser II grass species were observed in Alfred Nzo (55.6\%), Amathole (53.9\%) and Chris Hani (46.4\%) DMs. The decreaser grass species were much lower in Alfred Nzo (16.5\%), Amathole (13.8\%) and Chris Hani (21.8\%).

\subsection{Tick Species, Prevalence and Distribution}

A total of 34,929 ticks belong to five genera and 10 species were identified from 600 cattle. The most abundant tick genera was the Rhipicephalus including subgenus Boophilus (68.91\%), proceeded by Amblyomma (20.72\%), Hyalomma (8.64\%), Ixodes (1.22\%), and Haemaphysalis (0.51\%). The geographic distribution of most encountered ticks such as $A$. hebraeum (Figure 2), $R$. (B.) microplus, (Figure 3), R. evertsi evertsi (Figure 4) and $R$. appendiculatus were illustrated (Figure 5).

\subsection{Discussion}

Beef in the ECP is useful to both communal and smallholder productions. Communal farming system is characterised by farming within a common ground and as such, no one is having ownership of the land. Through LRAD programs, farmers that have shown great interest in emerging from communal to smallholder production are assisted and encouraged to apply for LRAD farms. Since the ECP is largely communal farming, South Africa embarked on the Red Meat Program in 2005 to promote marketing of livestock that involves beef production called

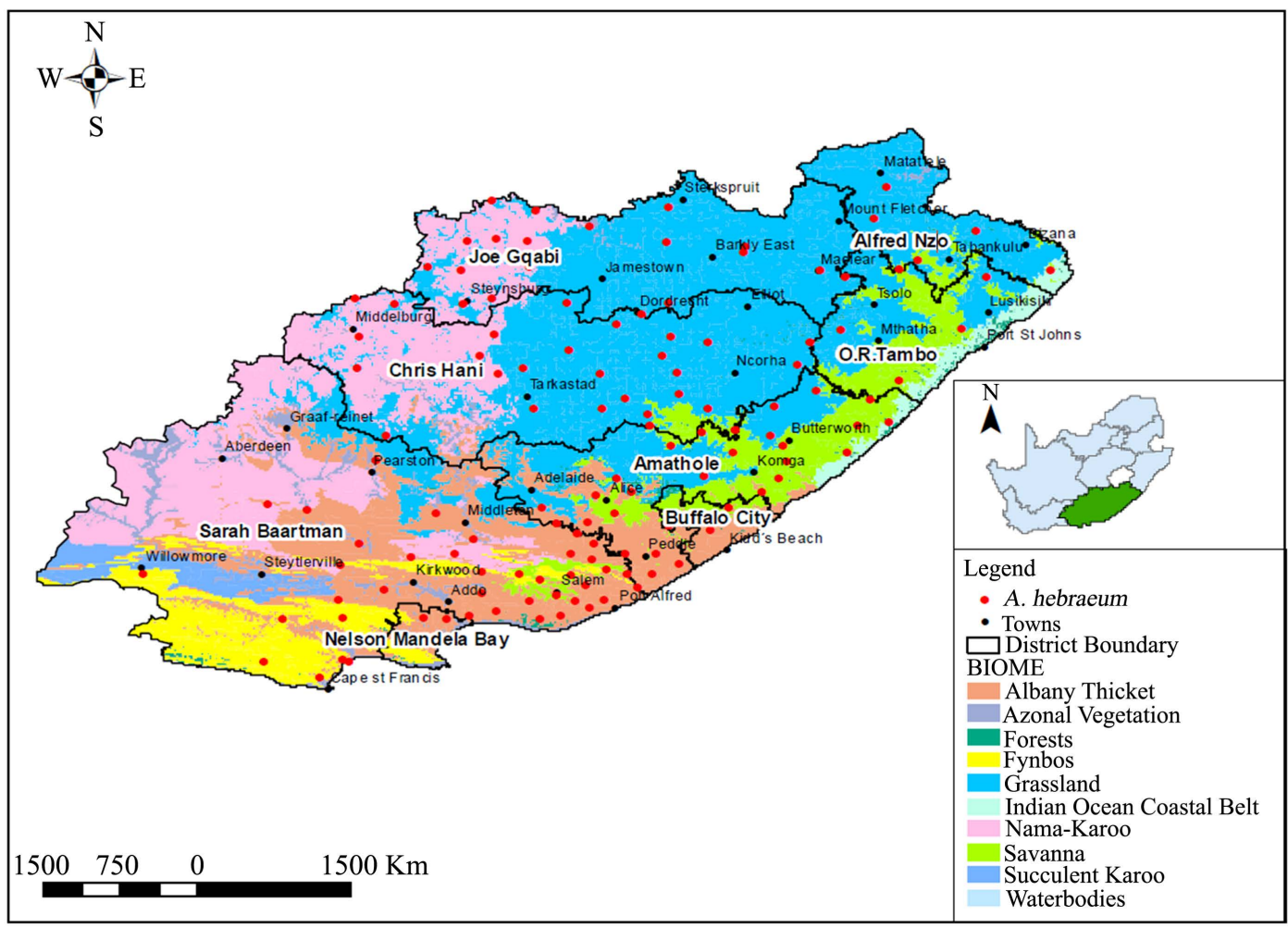

Figure 2. Map showing the tick distribution of the Amblyomma hebraeum in different districts of the Eastern Cape Province. 




Figure 3. Map showing the tick distribution of the Rhipicephalus (Boophilus) microplus in different districts of the Eastern Cape Province.



Figure 4. Map showing the tick distribution of the Rhipicephalus evertsi evertsi in different districts of the Eastern Cape Province. 


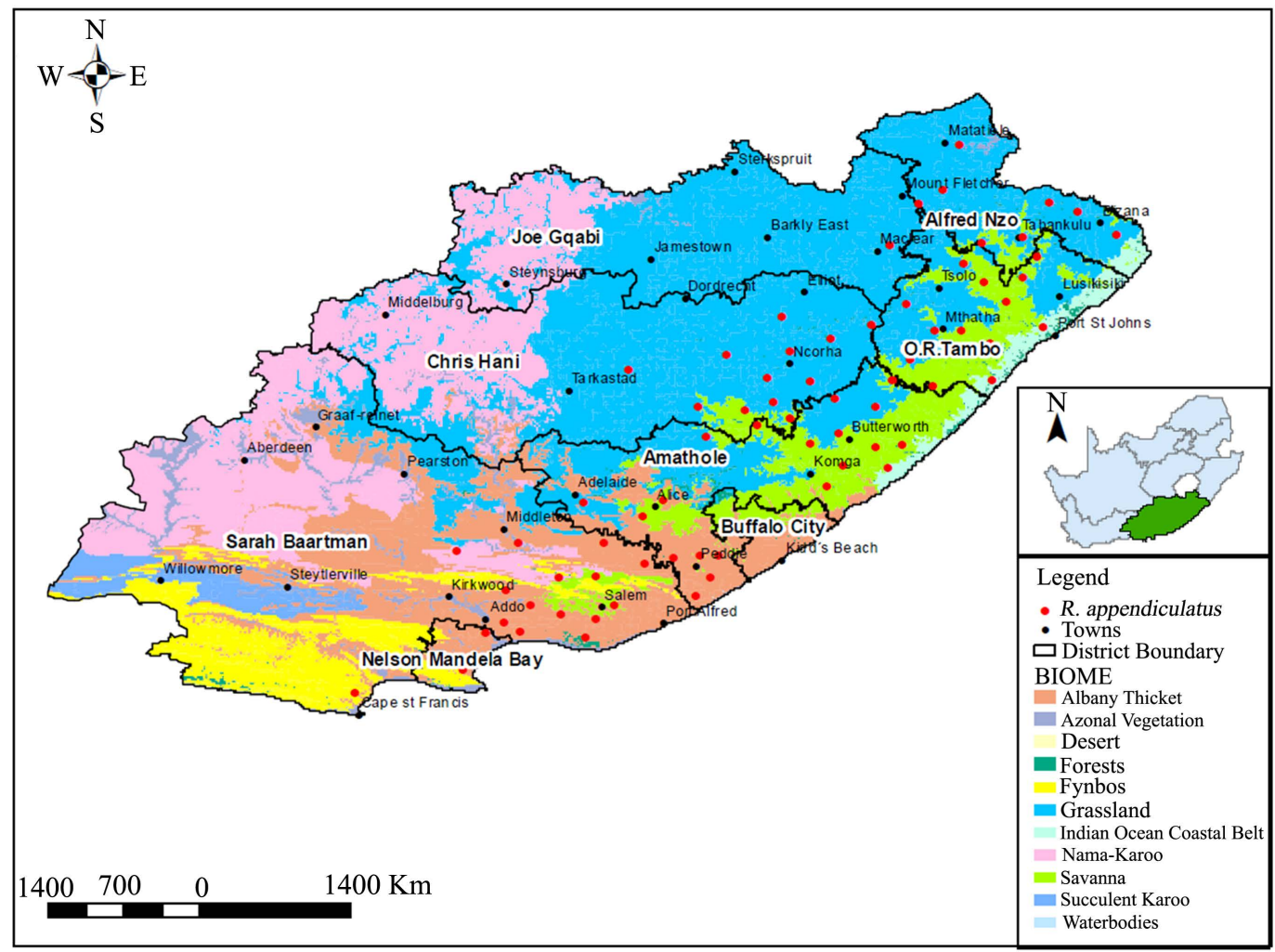

Figure 5. Map showing the tick distribution of the Rhipicephalus appendiculatus in different districts of the Eastern Cape Province.

the Eastern Cape Red Meat Project. This project was later (in 2008) taken up by National Agricultural Marketing Council (NAMC) and funded by Department of Rural Development and Land Reform (DRDLR) which led to the expansion to other provinces of the country [23].

We found that the factors obstructing beef meat production include marketing channels, poor animal conditions, lack of infrastructure, high price of medicine, shortage of feed, stock theft, and old animals to be marketed. Other studies from the ECP [24] [25] included that farmers were not satisfied with the low market prices they get from the auctions. This may be as a result of the large herd of the animals (cattle) which are in poor condition. As a way to improve communal or smallholder herd, 16 customer feeding centers were developed around the ECP to fatten cattle, therefore to improve the market price by weight gained. We found in line with a previous study, the poor supply of infrastructure for smallholder production is of great concern, thus, hampering the growth of smallholder production system [26] [27]. This could be attributed to differences in channels of marketing. For instance, the private sales are done for local people among neighbours and neighbouring communities mainly for cultural ceremonies or income for clearing fees for learners. In this regard, farmers do not experience any transport cost for dealing with the private sale.

Whereas in auctions, animals must be registered and be correctly identified through branding or tattooing with the owner's brand. Communal farmers 
usually suffer due to high transactional costs of selling or buying from auctioneers.

The socio-characteristics from the respondents in the ECP showed that males were higher (67\%) compared to females (33\%) in livestock rearing of ruminants [28] [29]. The participation of youth in farming is still a challenge but is improving and as a result, we found that $32 \%$ of farmers were between $21-25$ years of farming experience, although the highest number of farmers (26\%) were between the ages of $41-50$ years old, proceeded by $51-60$ years old (21\%). From this study, it is quite interesting to find out that more youths participated in agricultural activities in contrast to other previous records [30] [31]. More so, this study found a strong positive relationship between livestock farming and farming commodities.

In communally grazed area, the main source of nutrition is through forage on the veld and the animals extensively graze with no supplementary feeding. Species composition has been used to assess basal cover and production potential of the grasses on the veld. In turn, the veld condition gives information about the grazing capacity. Thus, from the ecological group of grass species encountered, the veld is in a good condition. Using the LRAD farms visited across the different DMs, we witnessed that numerous farms were overstocked in places like Alfred Nzo (80\%) and Chris Hani (70\%) DMs. A poor veld condition has been attributed to high stocking rates and continuous grazing [32] [33]. More so, Alfred Nzo and Chris Hani occur on a Grassland biome compared to Amathole district that is on a Savanna biome with main trees, bushes and grasses. Our findings showed that most of the Amathole district farms were understock (80\%) and this may be due to the differences in the agro-ecological zones. Also, despite being understocked, assessment showed mismanagement of the veld increaser II grass species (e.g. Aristida congesta, Eragrostis curvula and Sporobolus africanus) [3]. Increaser species is an indication of poor veld condition as result of light, moderate or heavy overgrazing [11]. Likewise, a veld in good condition is characterised by dominance of decreaser grass species (e.g., Digitaria eriantha, Panicum maximum and Themeda trianda). All assessed farms have low numbers of decreaser species. Land degradation is caused by overgrazing on communal rangelands [34] and this has threatened both communal and commercial properties with an estimated value of US $\$ 40$ billion per annum [35]. Indirectly, this contributes to lower production and poor performance in beef production.

In any farming system, ticks and tick-borne diseases threaten livestock production. In the present study, ticks of the genus Amblyomma, Hyalomma, Rhipicephalus and subgenus Boophilus were encountered. These genera are comprised of tick species of major concern in the livestock sector of South Africa [11] [12] [15]. Our study found that Rhipicephalus including subgenus Boophilus were most numerous ticks which were prevalent at $68.91 \%$, proceeded by South African bont tick i.e. Amblyomma (20.72\%), and Hyalomma (8.64\%). Based on tick distribution (Figures 2-5), the brown ear tick i.e. R. appendiculatus attaches to the ear of a host and also causes corridor disease and East Cost 
Fever (ECF) in Africa [20]. Another tick species of interest is the $R$. evertsi evert$s i$ which normally affects the perineum region causing loss of blood from a host. Tick species such as the $A$. hebraeum and $H$. rufipes are characterised by medium to long mouth parts that are capable for damaging the skin of the host [20]. Apart from this, A. hebraeum is among the major occurring ticks in ECP and is causing heart water disease (Ehrlichiosis) in ruminants. On the other hand, a one host tick, $R$. microplus has a wide distribution in the province and has replaced the indigenous tick ( $R$. decoloratus) in most parts of the country [15] [16] [36]. The $R$. microplus is also causing huge stress in cattle farming by vectoring the African red water and Asiatic red water (bovine babesiosis) in a host [15]. Records have found with surprise, that both $A$. hebraeum and $R$. microplus are now prevalent on the inland of the ECP [12]. Previously, tick species such as $R$. microplus were not usually found in the cooler region of the ECP [15]. In communal rangelands, government provides chemicals to control ticks weekly during the summer and winter when ticks are much. Conversely, when resources from government are scarce, tick burden becomes intense thereby causing mortality of the host [25] [37].

\section{Conclusion}

The study outlined constraints faced by low input-farming areas and is bringing solutions that can be used to improve the farming conditions. Most farming areas are overgrazed and invaded by unpalatable species such as Increaser grass species. The poor conditions play a role in poor animal performance in terms of production and poor body conditions. This is compounded further by ticks and TBDs. There is a need for more tailored interventions which encourage government and stakeholders to assist farmers for infrastructure development, to get access to the credit, improve marketing channels so that they might be able to compete in the commercial sector. If the aforementioned constraints can be resolved, the low-input farmers can achieve competitive levels of production. This will then translate to the sustainable development goal of South Africa to alleviate poverty and reduce inequality in agriculture. However, it is recommended that farmers farm according to their carrying capacity and stocking rate, where government rangeland scientists provide assistance free to farmers.

\section{Conflicts of Interest}

The authors declare that they have no conflict of interest with regard to the entirety of this work.

\section{References}

[1] World Bank (2009) Minding the Stock: Bringing Public Policy to Bear on Livestock Policy. World Bank, Washington DC.

[2] Department of Agriculture, Forestry and Fisheries (DAFF) (2009) Economic Review of the South African Agriculture, 2008/2009 Pretoria: Directorate Agricultural Statistics. 
[3] Mucina, L. and Rutherford, M.C. (2006) The Vegetation of South Africa, Lesoto and Swaziland. Strelitzia 19. South African National Biodiversity Institute, Pretoria.

[4] Anon (2019) Agricultural Statistics. National Department of Agriculture, Republic of South Africa.

[5] Ainslie, A., Thembela, K., Lungisile, N., Zolile, N. and Stephen, T. (2002) Cattle Ownership and Prodution in the Communal Areas of the Eastern Cape, South Africa. Programme for Land and Agrarian Studies, 41, 1475-1485.

[6] Nqeno, N., Chimonyo, M., Mapiye, C. and Marufu, M.C. (2009) Ovarian Activity, Conception and Pregnancy Patterns of Cows in the Semiarid Communal Rangelands in the Eastern Cape Province of South Africa. Animal Reproductive Science, 118, 140-147. https://doi.org/10.1016/j.anireprosci.2009.07.006

[7] Musemwa, L., Mushunje, A., Chimonyo, M. and Mapiye, C. (2010) Low Cattle Market Off-Take Rates in Communal Production Systems of South Africa: Causes and Mitigation Strategies. Journal of Sustainable Development in Africa, 12, 209-226.

[8] Ndoro, J.T., Mudhara, M. and Chimonyo, M. (2015) Farmers' Choice of Cattle Marketing Channels under Transaction Cost in Rural South Africa: A Multinomial Logit Model. African Journal of Forage and Forage Science, 32, 243-252. https://doi.org/10.2989/10220119.2014.959056

[9] Mdladla, K., Dzomba, E.F. and Muchadeyi, F.C. (2016) Characterization of the Village Goat Production Systems in the Rural Communities of the Eastern Cape, KwaZulu-Natal, Limpopo and North West Provinces of South Africa. Tropical Animal Health and Production, 49, 515-527. https://doi.org/10.1007/s11250-017-1223-x

[10] National Planning Commission (2011) National Development Plan 2030: Our Future-Make It Work. http://www.npconline.co.za/

[11] Yapi, T.Y., O’Farrell, P.J., Dziba, L.E. and Esler, K.J. (2018) Alien Tree Invasion into a South African Montane Grassland Ecosystem: Impact of Acacia Species on Rangeland Condition and Livestock Carrying Capacity. International Journal of Biodiversity Science, Ecosystem Services \& Management, 14, 105-116.

https://doi.org/10.1080/21513732.2018.1450291

[12] Nyangiwe, N., Horak, I.G., van der Mescht, L. and Matthee, S. (2017) Range Expansion of the Economically Important Asiatic Blue Tick, Rhipicephalus microplus, in South Africa. Journal of South African Veterinary Association, 88, Article ID: 1482.

[13] Mtshali, M.S., De Waal, D.T. and Mbati, P.A. (2004) A Sero-Epidemiological Survey of Blood Parasites in Cattle in the North-Eastern Free State, South Africa. Onderstepoort Journal of Veterinary Research, 71, 67-75.

[14] Marufu, M.C., Chimonyo, M., Mapiye, C. and Dzama, K. (2011) Tick Loads in Cattle Raised on Sweet and Sour Rangelands in the Low-Input Farming Areas of South Africa. Tropical Animal Health and Production, 43, 307-313. https://doi.org/10.1007/s11250-010-9690-3

[15] Nyangiwe, N., Goni, S., Hervé-Claude, L.P., Ruddat, I. and Horak, I.G. (2011) Ticks on Pastures and on Two Breeds of Cattle in the Eastern Cape Province, South Africa. Onderstepoort Journal of Veterinary Research, 78, E1-E9.

[16] Nyangiwe, N., Harrison, A. and Horak, I.G. (2013) Displacement of Rhipicephalus decoloratus by Rhipicephalus microplus (Acari: Ixodidae) in the Eastern Cape Province, South Africa. Experimental Applied and Acarology, 61, 371-382. https://doi.org/10.1007/s10493-013-9705-7 
[17] Botai, C.M., Joel O., Botai, J.O., Abiodun, M., Adeola, A.M., de Wit, J.P., Ncongwane, K.P., Nosipho, N. and Zwane, N.N. (2020) Drought Risk Analysis in the Eastern Cape Province of South Africa: The Copula Lens. Water, 12, 1938-1957. https://doi.org/10.3390/w12071938

[18] Scogings, P.F., Beckerling, A.C. and Trollope, W.S.W. (1994) Simplified Techniques for Assessing Range Condition for Livestock Production: An Example from Ciskei. Development Southern Africa, 11, 229-240. https://doi.org/10.1080/03768359408439745

[19] Okwuonu, E.S., Andong, F.A. and Ugwuanyi, I.K. (2021) Association of Ticks with Seasons, Age, and Cattle Color of North-Western Region of Nigeria. Scientific African, 12, e00832. https://doi.org/10.1016/j.sciaf.2021.e00832

[20] Walker, A.R., Bouattour, A., Camicas, J.L., Estrada-Pena, A., Horak, I.G., Latif, A., Pegram, R.G. and Preston, P.M. (2003) Ticks of Domestic Animals in Africa: A Guide to Identification of Species. Bioscience Reports, Edinburgh.

[21] Statistical Analysis System (SAS) (2003) Statistical Analysis System Institute Inc. Users Guide, Version 9, Cary, NC.

[22] Quantum GIS Development Team (2015) Quantum GIS Geographic Information System, Open Source Geospatial Foundation Project. http://qgis.osgeo.org

[23] Sotsha, K. and Fakudze, B. (2018) Factors Influencing Communal Livestock Farmers' Participation into the National Red Meat Development Programme (NRMDP) in South Africa: The Case of the Eastern Cape Province. OIDA International Journal of Sustainable Development, 11, 73-80.

[24] Musemwa, L., Chagwiza, C., Sikuka, W., Fraser, G., Chimonyo, M. and Mzileni, N. (2007) Analysis of Cattle Marketing Channels Used by Small Scale Farmers in the Eastern Cape Province, South Africa. Livestock Research for Rural Development, 19, Article ID: 131. http://www.lrrd.org/lrrd19/9/muse19131.htm

[25] Nqeno, N., Chimonyo, M. and Mapiye, C. (2011) Farmers' Perceptions of the Causes of Low Reproductive Performance in Cows Kept under Low-Input Communal Production Systems in South Africa. Tropical Animal Health and Production, 43, 315-321. https://doi.org/10.1007/s11250-010-9691-2

[26] Lahiff, E. and Cousins, B. (2005) Smallholders Agriculture and Land Reform in South Africa. Institute of Development Studies, 36, 127-131.

https://doi.org/10.1111/j.1759-5436.2005.tb00209.x

[27] Musemwa, L., Mushunje, A., Chimonyo, M., Fraser, G., Mapiye, C. and Muchenje, V. (2008) Nguni Cattle Marketing Constraints and Opportunities in the Communal Areas of South Africa: Review. African Journal of Agricultural Research, 3, 239-245.

[28] Yawa, M., Nyangiwe, N., Jaja, I.F., Kadzere, C.T. and Marufu, M.C. (2020) Communal Cattle Farmer's Knowledge, Attitudes and Practices on Ticks (Acari: Ixodidae), Tick Control and Acaricide-Resistance. Tropical Animal Health and Production, 52, 3005-3013. https://doi.org/10.1007/s11250-020-02319-1

[29] Gebre, G.G., Isoda, H., Rahut, D.B., Amekawa, Y. and Hisako, N. (2019) Gender Differences in Agricultural Productivity: Evidence from Maize Farm Households in Southern Ethiopia. GeoJournal, 86, 843-864.

https://doi.org/10.1007/s10708-019-10098-y

[30] Chenyambuga, S.W., Waiswa, C., Saimo, M., Ngumi, P. and Gwakisaet, P.S. (2010) Knowledge and Perceptions of Traditional Livestock Keepers on Tick-Borne Diseases and Sero-Prevalence of Theileria parva around Lake Victoria Basin. Livestock Research for Rural Development, 22, Article ID: 135. http://www.lrrd.org/lrrd22/7 
[31] Mdungela, N.M., Bahta, Y.T. and Jordaan, A.J. (2017) Indicators for Economic Vulnerability to Drought in South Africa. Development in Practice, 27, 1050-1063. https://doi.org/10.1080/09614524.2017.1361384

[32] Puttick, J.R., Hoffman, M.T. and Gambiza, J. (2014) The Influence of South Africa's Post-Apartheid Land Reform Policies on Bush Encroachment and Range Condition: A Case Study of Fort Beaufort's Municipal Commonage. African Journal of Range \& Forage Science, 31, 135-145. https://doi.org/10.2989/10220119.2014.880943

[33] Muller, M. and Shackleton, S.E. (2014) Perceptions of Climate Change and Barriers to Adaptation amongst Commonage and Commercial Livestock Farmers in the Semi-Arid Eastern Cape Karoo. African Journal of Range \& Forage Science, 31, 1-12. https://doi.org/10.2989/10220119.2013.845606

[34] Palmer, A.R. and Bennett, J.E. (2013) Degradation of Communal Rangelands in South Africa: Towards an Improved Understanding to Inform Policy. African Journal of Range \& Forage Science, 30, 57-63.

https://doi.org/10.2989/10220119.2013.779596

[35] Food and Agriculture Organization of the United Nations (FAO) (2010) Land Degradation Assessment in Drylands (LADA): Assessing the Status Causes and Impact of Land Degradation. FAO, Rome.

[36] Tønnesen, M.R., Penzhorn, B.L., Bryson, N.R., Stoltsz, W.H. and Masibigiri, T. (2004) Displacement of Boophilus decoloratus by Boophilus microplus in the Soutpansberg Region, Limpopo Province, South Africa. Experimental and Applied Acarology, 32, 199-208. https://doi.org/10.1023/B:APPA.0000021789.44411.b5

[37] Moyo, B. and Masika, J.P. (2009) Tick Control Methods Used by Resource Limited Farmers and the Effect of Ticks on Cattle in Rural Areas of the Eastern Cape Province, South Africa. Tropical Animal Health and Production, 41, 517-523. https://doi.org/10.1007/s11250-008-9216-4 